\title{
Renibacterium salmoninarum in wild Arctic charr Salvelinus alpinus and lake trout $S$. namaycush from the Northwest Territories, Canada
}

\author{
B. W. Souter, A. G. Dwilow, K. Knight \\ Department of Fisheries and Oceans, Freshwater Institute, Central and Arctic Region, Winnipeg, Manitoba R3T 2N6, Canada
}

\begin{abstract}
Renibacterium salmoninarum was detected in 7 wild Arctic charr Salvelinus alpinus and 1 lake trout $S$. namaycush from 7 widely separated locations in the Northwest Territories, Canada. Overt disease signs, culture, and microscopic results indicated that all 8 of the fish were actively infected with the pathogen. Because salmonid enhancement activities have never been practised in the Northwest Territories the occurrence of the $R$. salmoninarum infections are believed to represent a natural distribution of the disease.
\end{abstract}

Bacterial kidney disease (BKD), caused by Renibacterium salmoninarum (Sanders \& Fryer 1981), is a chronic disease capable of causing significant mortalities in salmonids (Wood 1974, Fryer \& Sanders 1981, Warren 1983). Although BKD has been recognized primarily as a disease of propagated trout and salmon, it has been reported in free-ranging fish taken from freshwater and marine environments (Pippy 1969, Evelyn et al. 1973, Ellis et al. 1978, Mitchum et al. 1979, Banner et al. 1986). This report documents the first detection of $R$. salmoninarum from wild Arctic charr Salvelinus alpinus and lake trout $S$. namaycush from the Northwest Territories, Canada.

Materials and methods. Between August 1981 and September 1986 a total of 244 wild, anadromous Arctic charr and 1 lake trout were collected for examination from several widely separated geographic locations in the Northwest Territories (Fig. 1). Samples consisted of: (1) smears of kidney tissue and lesion material from 210 Arctic charr from the Jayco River, (2) 20 fresh, whole Arctic charr from Char Lake (Victoria Island), and (3) 14 Arctic charr and 1 lake trout caught from various waters by local commercial fishermen. The last group of fish showed anomalies and were shipped as frozen specimens. All 245 samples were collected by Department of Fisheries and Oceans (DFO) regional biologists and sent to the Fish Health Laboratory,
Freshwater Institute, Winnipeg, Manitoba, for examination.

Smears of kidney tissue and of internal and external lesion material, prepared in the field from the Jayco River fish, were stained using the direct fluorescent antibody staining technique (DFAT) (Bullock et al. 1980). The DFAT reagent was provided by the Biologics Section at the National Fish Health Laboratory, Kearneysville, West Virginia, USA.

Duplicate smears of kidney tissue, lesion exudate, ascites fluid and abnormal muscle tissue taken from the 35 fresh and frozen whole fish samples were prepared and examined following Gram or DFAT staining.

Fish were considered positive for Renibacterium salmoninarum when fluorescing diplobacilli of typical size, shape and fluorescence were observed.

Samples from the above 35 fish were also streaked onto plates of KDM-2 medium (Evelyn 1977) and incubated at $15^{\circ} \mathrm{C}$ for a minimum of $30 \mathrm{~d}$. Plates were examined for the presence of small, slow growing, creamy-white colonies. Growth usually became evident after $21 \mathrm{~d}$. Slide agglutination tests (Rabb et al. 1964) on purified bacterial growth were performed using anti-Renibacterium salmoninarum serum prepared at Connaught Laboratories, Willowdale, Ontario.

Results. Gross examination of the Jayco River fish was not possible because only tissue smears from these fish were received for examination. However, gross examination of the 35 fresh and frozen whole fish specimens received from the other sites revealed a variety of abnormal conditions. These included: 4 fish with raised, circular to oblong, fluid-filled blebs 1 to $3 \mathrm{~cm}$ high and 1.5 to $6.0 \mathrm{~cm}$ in diameter. Some blebs were associated with necrosis of the underlying musculature. A single fish had a grossly distended abdomen due to the accumulation of ascites fluid; and another 


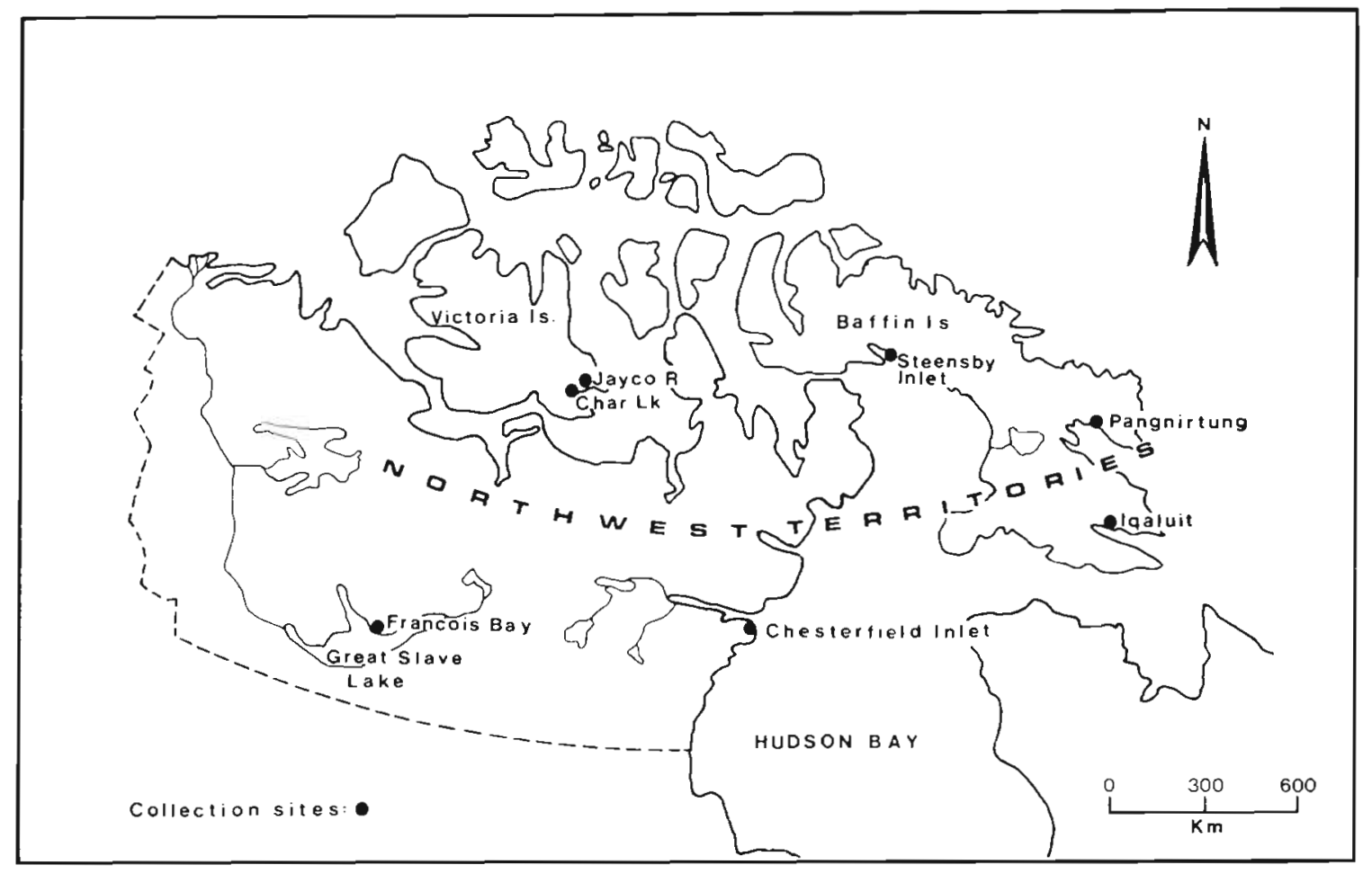

Fig. 1. Fish collection sites in the Northwest Territories. (Note: Iqaluit was formerly named Frobisher Bay)

had an unusual band of white, intact muscle tissue $(1.0 \mathrm{~cm} \mathrm{dia.})$ which extended the length of the flank adjacent to the gut cavity and which was easily distinguished from the normal orange-colored flesh. One fish was severely emaciated. The only overt evidence suggestive of BKD involving kidney tissue was observed in the specimen (from Steensby Inlet) with the distended abdomen; and only moderate swelling was present. Of the remaining 28 fish, 19 appeared normal, and 9 exhibited abrasions or wounds confined primarily to the flank areas. No bacterial pathogens were isolated from these 28 fish.

Table 1 summarizes the Renibacterium salmoninarum findings. Kidney smear samples from the Jayco River Arctic charr proved negative for $R$. salmoninarum, using DFAT. However, fluorescing diplobacilli typical of $R$. salmoninarum were observed in stained smears of both the exudate from a single large external bleb and a visceral tissue homogenate from 1 fish.

From the whole fish samples received, Renibacterium salmoninarum was detected in 7 of 35 fish. Four of the 7 positive fish had large, fluid-filled blebs which were heavily infected with $R$. salmoninarum. In only one of these fish (the Chesterfield Inlet specimen) was the pathogen also detected in the kidney. The presence of $R$. salmoninarum in the unusual muscle tissue of the Arctic charr from Pangnírtung may have been the result of contamination when the fish was cut. The kidney of the emaciated Arctic charr from Char Lake appeared grossly normal; however, examination of DFAT-stained kidney material indicated that this fish was heavily infected (50 to 100 organisms per field).

Unfortunately, we were unable to culture the organism from this fish. Bacterial kidney disease was not believed responsible for the emaciated condition of this fish. Rather, the fish was probably a spawner that had not fed actively at sea during the preceding summer. Of the 35 whole fish examined, only the single Steensby Inlet Arctic charr demonstrated any pathology of the kidney (it was moderately swollen). Both the kidney and ascites fluid from this fish were positive for the KD bacillus.

Three detection methods were used to increase the chances of detecting Renibacterium salmoninarum. No attempt was made to compare detection methods because 15 of the samples were received frozen, and had been held frozen for long periods prior to shipment under conditions $\left(-20^{\circ} \mathrm{C}\right)$ less than optimal for ensuring the viability of $R$. salmoninarum (Evelyn 1978). In spite of this, $R$. salmoninarum was cultured from lesion material from 3 frozen samples and identified by slide agglutination. This confirmed the results obtained from stained preparations.

Discussion. The presence of clinical signs combined with staining and culture results indicates that 7 Arctic 
Table 1. Salvelinus alpinus and S. namaycush. Summary of Renibacterium salmoninarum (Rs) detections in wild Arctic charr and lake trout from various locations in the Northwest Territories, Canada

\begin{tabular}{|c|c|c|c|c|c|c|c|c|}
\hline \multirow[t]{2}{*}{ Date } & \multirow[t]{2}{*}{ Location } & \multirow[t]{2}{*}{ Species } & \multirow{2}{*}{$\begin{array}{l}\text { Number } \\
\text { examined }\end{array}$} & \multirow{2}{*}{$\begin{array}{l}\text { No. RS } \\
\text { positive }\end{array}$} & \multirow{2}{*}{$\begin{array}{l}\text { Material } \\
\text { examined }\end{array}$} & \multicolumn{3}{|c|}{ Method of detection ${ }^{1}$} \\
\hline & & & & & & GS & DFAT & KDM-2 \\
\hline Aug 81 & Jayco R. & Arctic charr ${ }^{2}$ & 210 & 1 & $\begin{array}{l}\text { Lesion }^{5} \\
\text { Visceral } \\
\text { homogenate }\end{array}$ & $\begin{array}{l}N D \\
N D\end{array}$ & $\begin{array}{l}+ \\
+\end{array}$ & $\begin{array}{l}N D \\
N D\end{array}$ \\
\hline Aug 84 & $\begin{array}{l}\text { Chesterfield } \\
\text { Inlet }\end{array}$ & Arctic charr ${ }^{3}$ & 1 & 1 & $\begin{array}{l}\text { Kidney } \\
\text { Lesion }^{5}\end{array}$ & $\begin{array}{l}- \\
+\end{array}$ & $\begin{array}{l}+ \\
+\end{array}$ & $\begin{array}{l}+ \\
+\end{array}$ \\
\hline Mar 85 & Pangnirtung & Arctic charr ${ }^{3}$ & 5 & 2 & $\begin{array}{l}\text { Kidney } \\
\text { Lesion }^{5} \\
\text { Kidney } \\
\text { Muscle }\end{array}$ & $\begin{array}{l}- \\
+ \\
+ \\
+\end{array}$ & $\begin{array}{l}- \\
+ \\
+ \\
+\end{array}$ & $\begin{array}{l}- \\
- \\
- \\
-\end{array}$ \\
\hline Маг 85 & Steensby Inlet & Arctic charr ${ }^{3}$ & 1 & 1 & $\begin{array}{l}\text { Kidney } \\
\text { Ascites fluid }\end{array}$ & $\begin{array}{l}+ \\
+\end{array}$ & $\begin{array}{l}+ \\
+\end{array}$ & - \\
\hline Jul 85 & Iqaluit & Arctic charr ${ }^{3}$ & 7 & 1 & $\begin{array}{l}\text { Kidney } \\
\text { Lesion }^{5}\end{array}$ & $\begin{array}{l}- \\
+\end{array}$ & $\begin{array}{l}- \\
+\end{array}$ & $\begin{array}{l}- \\
+\end{array}$ \\
\hline Sep 86 & Char Lake & Arctic charr ${ }^{4}$ & 20 & 1 & Kidney & ND & + & - \\
\hline Sep 86 & Francois Bay & Lake trout ${ }^{3}$ & 1 & 1 & $\begin{array}{l}\text { Kidney } \\
\text { Lesion }^{5}\end{array}$ & + & $\begin{array}{l}- \\
+\end{array}$ & $\begin{array}{l}- \\
+\end{array}$ \\
\hline $\begin{array}{l}{ }^{1} \text { Metho } \\
\text { improv } \\
{ }^{2} \text { Sample } \\
{ }^{3} \text { Whole } \\
{ }^{4} \text { Whole } \\
{ }^{5} \text { Lesion } \\
\text { ND: not }\end{array}$ & $\begin{array}{l}\text { of detection: GS } \\
\text { ed culture mediur } \\
\text { consisted of sme } \\
\text { ish received froze } \\
\text { ish received fresh } \\
\text { : external surface } \\
\text { lone }\end{array}$ & $\begin{array}{l}\text { Gram stain; DF } \\
\text { n for } R \text {. salmoni } \\
\text { ars of kidney tis } \\
\text { en } \\
\text { lesion(s) (blebs }\end{array}$ & $\begin{array}{l}\text { direct fluore } \\
m \text { (Evelyn } 15 \\
\text { and lesion } m\end{array}$ & $\begin{array}{l}\text { antibody } \\
\text { only }\end{array}$ & ning technique & & 80); 1 & \\
\hline
\end{tabular}

charr and 1 lake trout were infected with Renibacterium salmoninarum. These results represent the first reported occurrence of $\mathrm{BKD}$ in anadromous Arctic charr and wild lake trout from the Northwest Territories. These findings also suggest that $R$. salmoninarum is widely distributed over this vast area. These fish are believed to be naturally infected because salmonid enhancement activities have never been practised in the Northwest Territories ( $R$. Moshenko, Department of Fisheries and Oceans, Central and Arctic Region, Winnipeg, Manitoba, pers. comm.).

The presence of overt disease signs together with the culture and microscopic results indicated that the 8 Renibacterium salmoninarum-positive fish had chronic, active infections which, over time, could have resulted in the death of these fish. Because $R$. salmoninarum is transmitted both vertically (Evelyn et al. 1984, 1986) and horizontally (Mitchum \& Sherman 1981), the pathogen can be expected to persist in the affected populations.

The present and potential economic impact of these infections in the Northwest Territories is unknown. Arctic charr represent an important commercial and sport fishery in the Northwest Territories, and any fish captured which exhibits overt pathology due to Renibacterium salmoninarum or other disease agents would likely be considered undesirable and of little value.

Acknowledgements. We thank C. Dahl, L. Dahlke, B. Wong, D. Vincent, D. Kaomayok and D. Smith for their assistance in collecting the field samples and Dr R. Kelly and A. Kristofferson for reviewing the manuscript.

\section{LITERATURE CITED}

Banner, C. R., Long, J. J., Fryer, J. L., Rohovec, J. S. (1986). Occurrence of salmonid fish infected with Renibacterium salmoninarum in the Pacific Ocean. J. Fish Dis. 9: 273-275

Bullock, G. L., Griffin, B. R., Stuckey, H. M. (1980). Detection of Corynebacterium salmoninus by direct fluorescent antibody test. Can. J. Fish. Aquat. Sci. 37: 719-721

Ellis, R. W. Novotny, A. J., Harrell, L. E. (1978). Case report of kidney disease in a wild chinook salmon, Oncorhynchus tshawytscha, in the sea. J. Wildl. Dis. 14: 120-123

Evelyn, T. P. T. (1977). An improved growth medium for the kidney disease bacterium and some notes on using the medium. Bull. off. int. Epiz. 87: 511-513

Evelyn, T. P. T (1978). Sensitivities of bacterial kidney disease 
detection methods with special remarks on the culture method. In: Proceedings of the Third Biennial Fish Health Section/AFS and Ninth Annual Midwest Fish Disease Workshops. August 15-18, 1978. American Fisheries Society, Kansas City, Missouri, p. 1-2

Evelyn, T. P. T., Hoskins, G. E., Bell, G. R. (1973). First record of bacterial kidney disease in an apparently wild salmonid in British Columbia. J. Fish. Res. Bd Can. 30: 1578-1580

Evelyn, T. P. T., Ketcheson, J. E., Prosperi-Porta, L. (1984). Further evidence for the presence of Renibacterium salmoninarum in salmonid eggs and for the failure of povidone-iodine to reduce the intra-ovum infection rate in water-hardened eggs. J. Fish Dis. 7: 173-182

Evelyn, T. P. T., Prosperi-Porta, L., Ketcheson, J. E. (1986). Persistence of the kidney-disease bacterium, Renibacterium salmoninarum, in coho salmon, Oncorhynchus kisutch (Walbaum), eggs treated during and after water hardening with povidone-iodine. J. Fish Dis. 9: 461-464

Fryer, J. L., Sanders, J. E. (1981). Bacterial kidney disease in salmonid fish. Ann. Rev. Microbiol. 35: 273-298

Mitchum. D. L., Sherman, L. E., Baxter, G. T. (1979). Bacterial kidney disease in feral populations of brook trout (Salvelinus fontinalis), brown trout (Salmo trutta), and rainbow trout (Salmo gairdneri). J. Fish. Res. Bd Can. 36 $1370-1376$

Mitchum, D. L., Sherman, L. E. (1981). Transmission of bacterial kidney disease from wild to stocked hatchery trout. Can. J. Fish. Aquat. Sci. 38: 547-551

Pippy, J. H. C. (1969). Kidney disease in juvenile Atlantic salmon (Salmo salar) in the Margaree River J. Fish. Res. Bd Can. 26: 2535-2537

Rabb, L., Cornick, J. W., McDermott, L. A. (1964). A microscopic slide agglutination test for the presumptive diagnosis of furunculosis in fish. Prog. Fish-Cult. 26: 118-119

Sanders, J. E., Fryer, J. L. (1980). Renibacterium salmoninarum gen. nov., sp. nov, the causative agent of bacterial kidney disease in salmonid fishes. Int. J. Syst. Bacteriol. 30: 496-502

Warren, J. W. (1983). Important diseases of salmonid fishes Bacterial kidney disease. In: Meyer, F. P., Warren, J. W., Carey, T. G. (ed.) A guide to integrated fish health management in the Great Lakes Basin, Part V. Great Lakes Fishery Commission, Ann Arbor, Michigan. Spec. Publ. 83-2: 185-192

Wood, J. W. (1974). Diseases of Pacific salmon, their prevention and treatment. Washington Department of Fisheries

Responsible Subject Editor: Dr T. Evelyn; accepted for printing on September 23, 1987 